\title{
Assessment of Physicochemical parameters and Water Quality Index of Vishwamitri River, Gujarat, India
}

\author{
Akshata Magadum ${ }^{1}$, Tejas Patel $^{1}$, Deepa Gavali ${ }^{2}$ \\ Gujarat Ecology Society, $3^{\text {rd }}$ Floor, Synergy House, Subhanpura, Vadodara, Gujarat, India
}

\begin{abstract}
Development and industrialisation exert pressure on the riverine system deteriorating the serenity of the rivers. The present study was carried out in Small River flowing through Vadodara city viz., Vishwamitri River. The study revealed better water quality before its entry into the urban area. Despite of presence of STPs, there is poor water quality affecting the aquatic life and ecology. The paper throws light on pollution aspect and need to develop decentralised treatment system to tackle the river pollution problem.
\end{abstract}

Keywords- BOD, COD, DO, Vishwamitri River, Water Quality Index.

\section{INTRODUCTION}

The rivers are the important sources of surface water and India is a blessed country and rightly referred to as Land of Rivers" because of numerous rivers and lakes crisscrossing the terrain and landscape. Apart from source of fresh water, rivers play major role in assimilation or transportation of municipal and industrial waste water. Riverine sediments play an important role as pollutant accumulator and often reflect the history of the river pollution (Jain, 2004). Sediments act as both carriers and sinks for contaminants in aquatic environments (Mishra and Dinesh 1991). Studies have shown that domestic and industrial sewage, agricultural wastes have polluted almost all of Indian rivers (Pani 1986). Most of these rivers have turned into sewage carrying drains. This poses a serious health problem to millions of people who continue to depend on this polluted water from the rivers. Major rivers present in Gujarat includes Sabaramti, Naramada, Mahi, Tapti and Purna. Apart from these there are small rivers running across the landscape. Most of these rivers receive industrial and domestic sewage before draining into the sea. However, monitoring of river pollution is done in the major rivers and smaller rivers are not monitored. Rivers like Sabarmati, Vishwamitri, Tapi and Aji rivers are loaded with tons of industrial pollution, sewage and garbage every day. The paper deals with one such river Vishwamitri river passing through Vadodara city. Rivers Present study deals with the aim to evaluate the key stresses responsible for deteriorating the water quality and to undertake the comparative study of upstream and downstream of river.

The present paper uses the WQI index to express the quality of water and is the major indices used to assess the pollution and one of the effective ways to create awareness among the public. Quality of water is defined in terms of its physical, chemical, and biological parameters (Almeida, 2007). Water quality index allows for a general analysis of water quality on many levels that affect a stream's ability to host life and whether the overall quality of water bodies poses a potential threat to various uses of water (Akkaraboyina and Raju 2012).

\section{STUDY AREA}

The Vishwamitri River is a seasonal river, which flows east to west between the Mahi and Narmada rivers in Gujarat, India. It originates in the hills of Pavagadh and flows west through the city of Vadodara and joins with the Dhadhar River and Khanpur River and empties into the Gulf of Khambat, near Khanpur village. A total of ten stations is selected, out of which station 1 to 6 represent outside the City limits and categoriesd as upstream whereas station 7 to 10 represents the location within the city. 


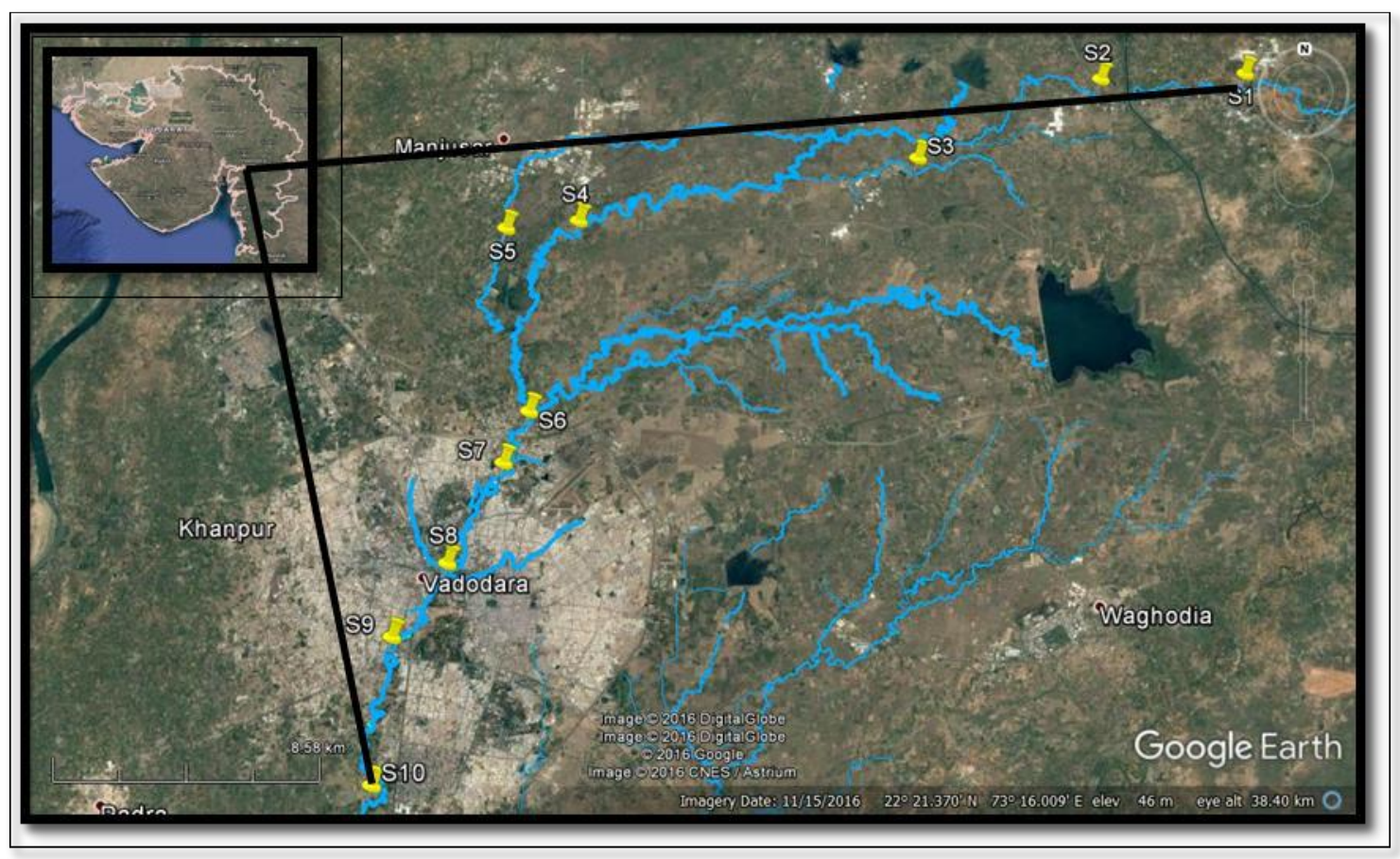

Fig.1: Sampling points of study area

\section{MATERIALS AND METHODOLOGY}

The study is carried out between Decembers to March 2017. The physical parameters like temperature, $\mathrm{pH}$, and conductivity is measured directly in the field using respective instruments. Dissolved oxygen was fixed in the field and around 2 litres of water collected for further analysis. A standard method was adopted for the water quality assessment (APHA). Chemical Oxygen Demand was estimated by Open Reflux method. Nitrite $\left(\mathrm{NO}_{2}-\mathrm{N}\right)$ was determined by Colorimetric method and Nitrates was estimated by Cadmium reduction method. Total phosphate is estimated by Ascorbic acid method. Silicate was estimated by Colorimetric method. Turbid metric method was used for the estimation of Sulphates. Statistical analysis carried out using the Statistical package SPSS (Version 20) and PAST (Version 7).

In this study the WQI was calculated by using the standards of drinking water quality recommended by BIS (1993) and ICMR (1975). The weighted arithmetic index method has been used for the calculation of WQI. Total 10 parameters $(\mathrm{pH}$, Conductivity, TDS, TSS, DO, BOD, Hardness, Nitrate, Flouride and Sulphate) were selected for calculating the WQI.

Further quality rating or sub index (qn) was calculated using the following expression-

$\mathrm{Qn}=100 \times\left[\mathrm{Vn}-\mathrm{Vo}_{\mathrm{o}}\right] /\left[\mathrm{Sn}-\mathrm{Vo}_{\mathrm{o}}\right]$

Where, $\mathrm{qn}=$ Quality rating for the nth water quality parameter.

$\mathrm{Vn}=$ Estimated value of the $\mathrm{n}^{\text {th }}$ parameter at a given sampling station.

$\mathrm{Sn}=$ Standard permissible value of the nth parameter.
Vo = Ideal value of nth parameter in a pure water.

Unit weight was calculated by a value inversely proportional to the recommended standard values

$\mathrm{Sn}$ of the corresponding parameters.

$\mathrm{Wn}=\mathrm{K} / \mathrm{Sn}$

Where, $\mathrm{Wn}=$ Unit weight for the nth parameter.

$\mathrm{Sn}=$ Standard value for $\mathrm{nth}$ parameter.

$\mathrm{K}=$ Constant for proportionality

The overall Water Quality Index (WQI) was calculated by aggregating the quality rating with the unit weight linearly.

$\mathbf{W Q I}=\Sigma q n \mathbf{W n} / \Sigma \mathbf{W n}$

\section{RESULTS AND DISCUSSIONS}

Water temperature ranged from $19^{\circ} \mathrm{C}$ to $24^{\circ} \mathrm{C}$. The water temperature is in accordance with the winter season, when the sampling is done.

The $\mathrm{pH}$ values in present study ranged from 6.8 (Station 3) to 8.3 (station 8). Similar $\mathrm{pH}$ range was reported in previous study (Deshkar et al., 2014). Thus, there is no change in the $\mathrm{pH}$ level of the water.

Conductivity showed positive correlation with TDS, TSS, BOD, Total phosphate and Sulphate (significant at 0.01 level), as conductivity is the sum of anions, cations, dissolved ions, sulphates, carbonates, bicarbonates, chlorides and others. The hierarchical cluster analysis carried out for Conductivity (Fig.2) for different stations reflected two major clusters. Cluster A included Stations 1 to 7 with low conductivity values ( 290 to $660 \mu$ s) and cluster $\mathrm{B}$ with station 8,9 and 10 showed higher conductivity ( 800 to $1340 \mu \mathrm{s}$ ). This shows that there is 
deterioration of water downstream of the river after it enters the city limits. The addition of industrial effluents and other domestic discharges has contributed to presence of higher ions (Nair et.al 1989 and Sugunan, 1989).

The chloride concentration in the present study increases as one moves downstream from station $3(20.99 \mathrm{mg} / \mathrm{l})$ to station $10(109.96 \mathrm{mg} / \mathrm{l})$. The presence of higher chlorides in the residential and commercial area of the river is reported (Hunt et al., 2012). Further, the relatively high concentration of Total nitrogen, Phosphates and Total phosphorus ions affect the conductivity which in turn influence the concentration of chlorinity.

The Total dissolved solid (TDS) varied from $290 \mathrm{mg} / \mathrm{L}$ (Station 3) to $810 \mathrm{mg} / \mathrm{L}$ (station 9) and the concentrations are within the prescribed limits of CPCB $(1500 \mathrm{mg} / \mathrm{l})$. The discharge from nearby areas at station 8 and 9 has contributed to higher TDS. At upstream stations there is less human influence into the river and water is comparatively clean compared to downstream stations. The chlrodies has also contributed to the TDS levels (Taylor, 1984).

Total suspended solid (TSS) of water depend on suspended particle of soil, silt and is directly related to the turbidity of water. The highest TSS value was recorded at station $9(410 \mathrm{mg} / \mathrm{L})$ and low recorded at station $3(110$ $\mathrm{mg} / \mathrm{l})$. The present result was higher compared to the previous study in the same river (Deshkar et al., 2014). The increased TSS values over the time period shows increase in discharge of untreated sewage into the river.

The Total hardness ranged between $104 \mathrm{mg} / \mathrm{L}$ (station 2) to $280 \mathrm{mg} / \mathrm{L}$ (station 8). The values increased from upstream to downstream. The higher values at the downstream stations may be due to the discharge of untreated sewage and effluents. Similar values were observed in Parna River (Pandey et.al, 2000).

The Dissolved oxygen (DO) showed marked difference in the riverine stretch. In the upstream stations DO ranged from $6.0 \mathrm{mg} / \mathrm{l}$ (station 1 and 3) to $11.3 \mathrm{mg} / \mathrm{l}$ (station 5). On the other hand DO was absent in the stations 6 to 10 . The low concentration of DO in the fresh water aquatic system indicates presence of high organic load (Yayyntas et al., 2007). The direct discharge of untreated sewage into the river has lead to anaerobic conditions. In the present study the cluster analysis has shown three clusters A, B and C. Cluster A includes the stations 1, 3, 4 and 6, while Cluster B includes 7, 8, 9 and 10 and cluster C includes station 3 and 5 . Incidentally cluster $C$ is distantly related with cluster A and B by more than $75 \%$. At these stations there is presence of higher DO, which is attributed to photosynthetic activity of the aquatic vegetation that release oxygen. The minimum of $3 \mathrm{mg} / \mathrm{L}$ dissolved oxygen is necessary for healthy fish and other aquatic life (Clair. et al., 2003). Thus, the water quality within the city limits is not suitable for aquatic life.

In the present study the concentrations of Biological oxygen demand (BOD) ranged from $3 \mathrm{mg} / \mathrm{L}$ (Station 1) to $92 \mathrm{mg} / \mathrm{L}$ (Station 10). Station 10 being the last station sampled showed the presence of high organic load because of cumulative effect. The untreated sewage disposal into the river may lead to the bacterial growth and consume the dissolved oxygen in the river resulting in oxygen depleted zone (Kulshrestha and Sharma, 2006; Kumar and Chopra, 2012).

The negative correlation observed between DO and BOD, both are inversely related as higher BOD represents oxygen depletion zone and demand represents more oxygen to degrade the organic pollutants present in the system. Chemical oxygen demand showed high significant positive relations with BOD, Nutrients and TDS but negative relation with DO. This indicates presence of industrial discharges that have influenced the water quality.

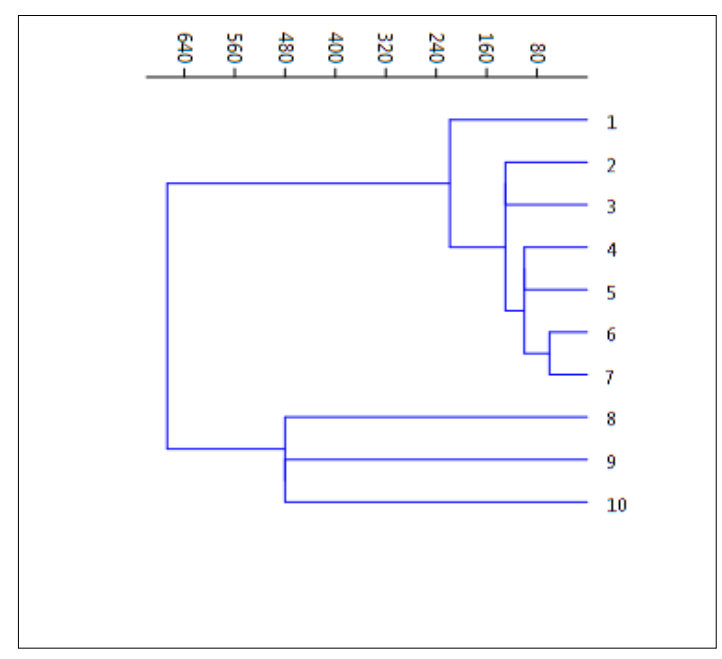

Fig.2: Euclidian cluster analysis of conductivity

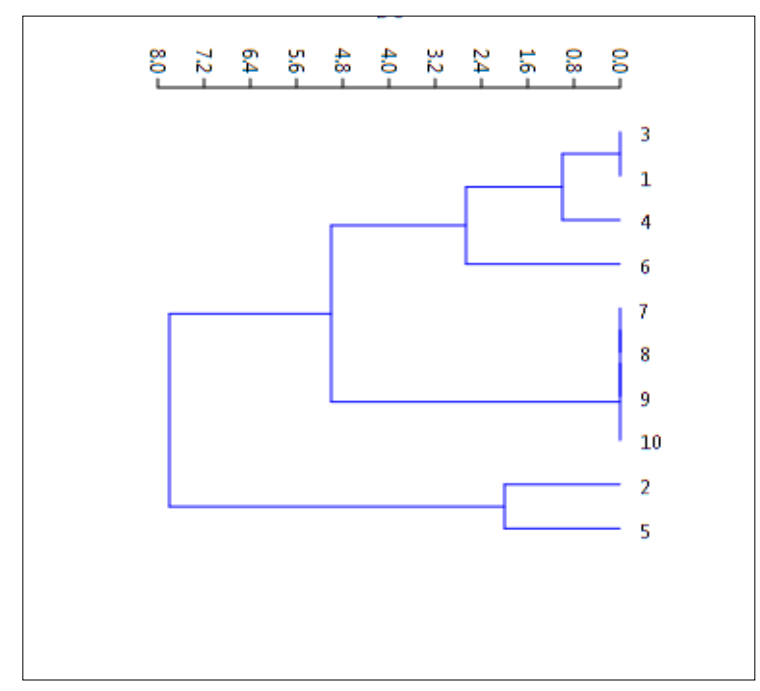

Fig.3: Euclidian cluster analysis of DO 


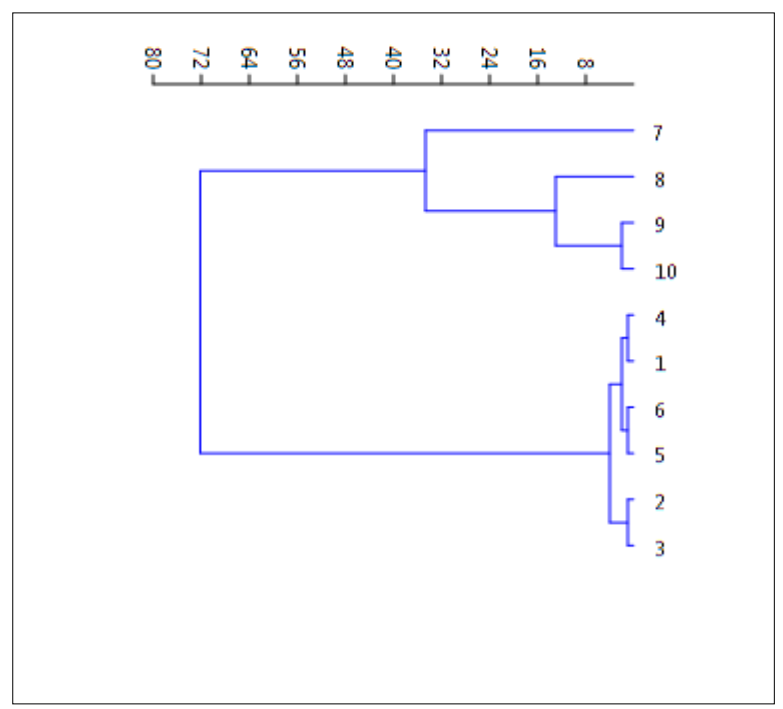

Fig.4: Euclidian cluster analysis of BOD

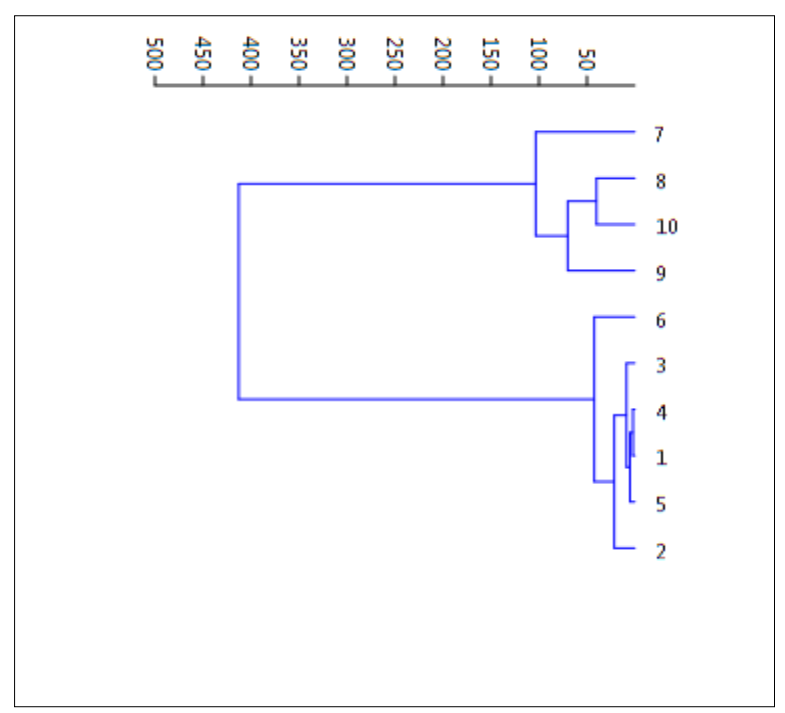

Fig.5: Euclidian cluster analysis of COD

The values of Chemical oxygen demand (COD) ranged from $40 \mathrm{mg} / \mathrm{L}$ (station 3) to $520 \mathrm{mg} / \mathrm{L}$ (station 7). The higher COD value was recorded at downstream stations because of direct discharge of industrial effluents and improper functioning of STPs. Further, the values of COD at downstream stations were above the permissible limits prescribed by CPCB (250 mg/L). The figure 5 cluster analysis depicts two clusters A and B; Cluster A includes stations 1 to 6 with similar water quality, while cluster B includes 7 to 10 . The COD values were noted higher compared to the earlier study (Deshkar et al., 2014) indicative of increase in pollution load because of expanding population.

The BOD to COD ratio differed in the riverine stretch. The BOD: COD value was more than 0.5 indicative of need for biological treatment of the water. On the other hand the BOD: COD ration was 0.1 at station 7 and 8 , indicates presence of toxic waste and there is need for tertiary treatment and stabilization. Thus, the water quality of the river in the urban limits is highly polluted.

In the present study the Nitrate concentration ranged from $0.006 \mathrm{mg} / \mathrm{L}$ to $0.263 \mathrm{mg} / \mathrm{L}$. The maximum concentration recorded at station $7(0.263 \mathrm{mg} / \mathrm{L})$ and minimum at station $1(0.006 \mathrm{mg} / \mathrm{L})$. The agricultural runoff, nitrate rich fertilizers and animal faeces into the river may lead to the higher values of nitrate (Tank et. al, 2013). The concentrations are within the CPCB prescribed limits.

The values of Nitrite ranged from $0.013 \mathrm{mg} / \mathrm{L}$ (station 6) to $0.291 \mathrm{mg} / \mathrm{L}$ (station 7 ). The presence of low nitrite value is indicative of conversion of nitrite to stable nitrate by microbial activity. This conversion has exerted pressure on the DO levels. Total nitrogen showed positive correlation with Nitrates, Nitrites as these are related. The increase in Total nitrogen value at downstream stations is recorded because of discharges from industrial effluent.

The values of Total phosphate ranged from $0.060 \mathrm{mg} / \mathrm{L}$ (station 2) to $0.800 \mathrm{mg} / \mathrm{l}$ (station 8). The major source of phosphates is domestic sewage and hence the value increases as one moves downstream of the riverine stretch. The values of Sulphate was reported high at station $10(375 \mathrm{mg} / \mathrm{L})$ and low at station $3(135 \mathrm{mg} / \mathrm{L})$.

Table.1: Results of water quality parameters

\begin{tabular}{|c|c|c|c|c|c|c|c|c|c|c|c|c|}
\hline $\begin{array}{c}\text { PARAMETER } \\
\text { S }\end{array}$ & $\begin{array}{c}\text { CPCB } \\
\text { standard } \\
s\end{array}$ & $\begin{array}{l}\text { UNIT } \\
\mathbf{S}\end{array}$ & S1 & $\mathbf{S 2}$ & S3 & S4 & S5 & S6 & S7 & S8 & S9 & S10 \\
\hline $\mathrm{pH}$ & $5.5-9.0$ & & 7.03 & 8.1 & 8.3 & 8.2 & 8.03 & 8.1 & 7.2 & 6.8 & 8.2 & 7.2 \\
\hline Temperature & - & ${ }^{\circ} \mathrm{C}$ & 20 & 24 & 22 & 23 & 20 & 23 & 20 & 23 & 20 & 24 \\
\hline Conductivity & - & $\mu \mathrm{s}$ & 660 & 420 & 290 & 460 & 560 & 490 & 430 & 1340 & 800 & 1280 \\
\hline TDS & 1500 & $\mathrm{mg} / \mathrm{L}$ & 560 & 460 & 290 & 400 & 480 & 420 & 600 & 800 & 810 & 780 \\
\hline TSS & 100 & $\mathrm{mg} / \mathrm{L}$ & 240 & 148 & 110 & 158 & 168 & 138 & 248 & 340 & 410 & 345 \\
\hline DO & 4 & $\mathrm{mg} / \mathrm{L}$ & 6 & 9.3 & 6 & 5 & 11.3 & 3 & 0 & 0 & 0 & 0 \\
\hline
\end{tabular}




\begin{tabular}{|c|c|c|c|c|c|c|c|c|c|c|c|c|}
\hline BOD & 30 & $\mathrm{mg} / \mathrm{L}$ & 3 & 8 & 9 & 4 & 5 & 6 & 5.2 & 78 & 90 & 92 \\
\hline COD & 250 & $\mathrm{mg} / \mathrm{L}$ & 51 & 45 & 40 & 70 & 68 & 65 & 520 & 420 & 370 & 460 \\
\hline Chloride & - & $\mathrm{mg} / \mathrm{L}$ & 39.9 & 37.9 & 20.9 & 33.9 & 71.9 & 34.9 & 87.9 & 107.9 & 979 & $\begin{array}{c}109 . \\
9\end{array}$ \\
\hline Total hardness & - & $\mathrm{mg} / \mathrm{L}$ & 150 & 104 & 148 & 130 & 133 & 140 & 190 & 280 & 200 & 190 \\
\hline $\begin{array}{l}\text { Calcium } \\
\text { hardness }\end{array}$ & - & $\mathrm{mg} / \mathrm{L}$ & 110 & 76 & 91 & 100 & 72 & 80 & 108 & 100 & 124 & 104 \\
\hline Nitrate & - & $\mathrm{mg} / \mathrm{L}$ & $\begin{array}{c}0.00 \\
6\end{array}$ & $\begin{array}{c}0.01 \\
6\end{array}$ & 0.042 & $\begin{array}{c}0.01 \\
3\end{array}$ & $\begin{array}{c}0.00 \\
8\end{array}$ & $\begin{array}{c}0.00 \\
3\end{array}$ & 0.263 & 0.014 & 0.035 & $\begin{array}{c}0.20 \\
0\end{array}$ \\
\hline Nitrite & 10 & $\mathrm{mg} / \mathrm{L}$ & $\begin{array}{c}0.03 \\
4\end{array}$ & $\begin{array}{c}0.02 \\
1\end{array}$ & 0.057 & $\begin{array}{c}0.01 \\
6\end{array}$ & $\begin{array}{c}0.03 \\
5\end{array}$ & $\begin{array}{c}0.01 \\
3\end{array}$ & 0.291 & 0.023 & 0.02 & $\begin{array}{c}0.09 \\
6\end{array}$ \\
\hline Total nitrogen & - & $\mathrm{mg} / \mathrm{L}$ & 0.41 & $\begin{array}{c}0.39 \\
2\end{array}$ & 0.329 & 0.3 & $\begin{array}{c}0.44 \\
6\end{array}$ & $\begin{array}{c}0.37 \\
2\end{array}$ & 0.715 & 1.874 & 1.976 & $\begin{array}{c}2.01 \\
3\end{array}$ \\
\hline Total phosphate & - & $\mathrm{mg} / \mathrm{L}$ & $\begin{array}{c}0.20 \\
0\end{array}$ & $\begin{array}{c}0.06 \\
0\end{array}$ & $\begin{array}{c}0.047 \\
0\end{array}$ & $\begin{array}{c}0.07 \\
6\end{array}$ & $\begin{array}{c}0.06 \\
0\end{array}$ & $\begin{array}{c}0.03 \\
3\end{array}$ & 0.093 & 0.800 & 0.500 & $\begin{array}{c}0.76 \\
0\end{array}$ \\
\hline Sulphate & 400 & $\mathrm{mg} / \mathrm{L}$ & 142 & 172 & 135 & 175 & 216 & 204 & 191 & 265 & 314 & 375 \\
\hline \multicolumn{3}{|c|}{ WQI $=\Sigma W n q n / \Sigma W n$} & 68 & 75 & 99.1 & 88.5 & $\begin{array}{c}116 . \\
5\end{array}$ & 78 & $\begin{array}{c}320.5 \\
1\end{array}$ & $\begin{array}{c}543.1 \\
8\end{array}$ & $\begin{array}{c}581.5 \\
2\end{array}$ & $\begin{array}{c}593 . \\
4\end{array}$ \\
\hline
\end{tabular}

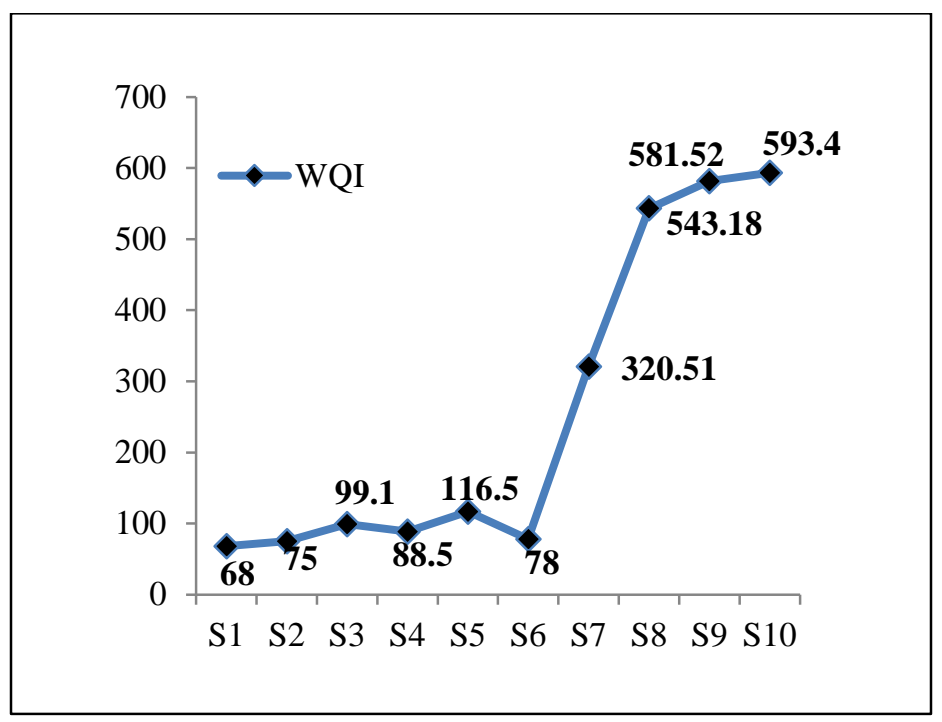

Fig.6: Graph of WQI

As per the WQI rating, the upstream stations (1 to 6) are categorized as $\mathrm{C}$ and $\mathrm{D}$ grade indicating that the water can be used for irrigation. However, the downstream stations are categorised as grade $\mathrm{E}$ indicative of presence of high pollution load and the water cannot be used for any purpose. Despite of presence of six STPs in Vadodara city, there is inefficiency in the functioning of the STPs leading to presence of high pollution in the river. The river pollution is a foremost issue with not only major river of India but also the minor rivers. As the urbanisation increases the problem of pollution is bound to increase and there is need to decentralise the sewage collection. Perhaps new technology of treatment has to be designed so as to reduce the pollution load of the rivers. In coming years, this would be an important issue for minor rivers as well.

\section{CONCLUSION}

From the present study it is concluded that the water quality of Vishwamitri River showed good quality and low pollution prior to its entry into the Vadodara city. The discharge of untreated sewage and dumping of solid waste in or on the bank of the river have contributed to poor water quality in the downstream locations. There is discrepancy in the functioning of the STPs and untreated sewage finds its way into the river system disturbing the ecology and aquatic life.

\section{ACKNOWLEDGMENTS}

The authors are thankful to Gujarat Ecology Society for providing the necessary facilities required to carry out the present study. 


\section{REFERENCES}

[1] Akkaraboyina M, Raju B: A Comparative Study of Water Quality Indices of River Godavari. Int J Eng Res Dev 2012, 2(3):29-34.

[2] Almeida, C. A., Quintar, S., Gonzalez. P., and Mallea, M. A.: Influence of urbanization and tourist activities on the water quality of the Portero de losFunes River (San Luis - Argentina). Environment Monitoring and Assessment. 2007, 133: 459 - 465.

[3] B. Sarwade and N. A. Kamble : Evaluation of physic chemical parameters of river Krishna, Sangli Maharashtra. Octa Journal of International Research. 2014, Vol. 2(4): 329-337.

[4] B.N., Gupta A.K., Mishra A.K., Das P.K.L. and Jha K., Ecological studies on river Panar of Araria (Bhihar) with special emphasis on its biological components, In pollution and biomonitoring of Indian rivers, Trivedy R.K. (ed), ABD Publishers, India, 2000, 130-147

[5] Clair N.: Chemistry for Environmental Engineering and Science. 5th Edn. New York: Tata McGraw-Hill. 2003.

[6] Deshkar S., Mewada K. and Gavali D.: Spatial difference in pollution levels across Vishwamitri River, International Journal of Environmental Biology, Universal Research Publications 2014.

[7] Gaur VK, Gupta SK, Pandey SD, Gopal K, Misra V :Distribution of heavy metals in sediment and water of river Gomti. Environ Monitor Assess 2005, 102:1-3

[8] Hunt M, E Herron and L Green: Chlorides in fresh water, URI watershed Watch: URIWW 2012, 4: 4.

[9] Kulshrestha H, Sharma S: Impact of mass bathing during Ardhkumbh on water quality status of River Ganga. Journal of Environmental Biology.2006, 27(2): 437-440.

[10] Kumar V, Chopra AK: Monitoring of physicochemical and microbial characteristics of municipal wastewater at treatment plant, Haridwar city (Uttarakhand) India. Journal of Environmental Science and Technology, 2012, 5(2): 109-118.

[11] Malik GM, Raval VH, Zadafiya SK and Patel AV: Idol immersion and PhysicoChemical properties of South Gujarat Rivers, India, Res.J.Chem.Sci,. 2012, 2(3):21-25.

[12] Merritts D, Dewet A and Menking K: Environmental Geology: An Earth System Science Approach. New York: W.H. Freeman and Company 1998.

[13] Mishra. S. G., Dinesh, D: Soil pollution, Ashing Publishing House 1991, New Delhi, India.

[14] Pani B. S: "Outfall diffusers", In Abstract of the National seminar on Air and water pollution, April 1986, University college of engineering, Burla
[15] Sharma RK, Agrawal M and Marshall FM: Effects of waste water irrigation on heavy metal accumulation in soil and plants. Paper presented at a National Seminar, Bangalore University, Bangalore. 2004, Abst. No. 7,pp.8

[16] Tank, S.K. and Chippa, R.C: Analysis of Water Quality of Halena Blocks in Bharatpur. International Journal of Scientific and Research Publications. 2013 $3,1-6$

[17] Taylor LE: Groundwater resources of the upper Susquehanna River Basin, Pennsylvania. Pennsylvania Geological Survey 4th Series, Water Resources Report. 1984 vol. 58, 136.

[18] Welch, P: Limnology, 2nd ed. Mc Graw Hill Book Co.1952 NewYork.

[19] Yayyantas, O. T., Yilmaz, S., Turkoglu, M., Colakoglu, F. A., Cakir, F:Seasonal variation of some heavy metal pollution with environmental and microbiological parameters in sub-basin Kocabas Stream (Biga, Canakkale, Turkey) by ICP-AES. Environ. Monit. Assess. 2007 (13) 4: pp 321-331. 